\title{
Students with ADHD: Social Skills, Behavioral Problems, Academic Performance, and Family Resources
}

\author{
Anaísa Leal Barbosa Abrahão ${ }^{1}$ \\ Luciana Carla dos Santos Elias
}

${ }^{1}$ Universidade de São Paulo, Ribeirão Preto, São Paulo, Brasil

\begin{abstract}
ADHD constitutes a developmental risk. The general aim was to identify social skills, behavior problems, academic performance and family resources of children with ADHD, with the specific aim being to compare students regarding indicators of ADHD and the use or not of medication. Participants were 43 Elementary Education I students ( $M=9.6$ years, $S D=1.5), 43$ parents $(M=39.1$ years, $S D=7.6)$ and 38 teachers $(M=43.1$ years, $S D=8.4)$. The instruments used were the Inventory of Social Skills, Behavior Problems and Academic Competence (SSRS-BR), Conners' Scale and the Inventory of Family Resources. The collection was carried out in public schools. The results showed that the students had scores higher than the reference sample in Behavior Problems and Social Skills and lower in classes of social skills and Academic Competence; the presence of family resources; and grades above 5.0 as a school mean. We concluded that there is a need for interventions with the studied population.

Keywords: ADHD; social skills; behavioral problems; academic performance and family resources.
\end{abstract}

Estudantes com TDAH: Habilidades Sociais, Problemas Comportamentais, Desempenho Acadêmico e Recursos Familiares

\begin{abstract}
Resumo
TDAH constitui risco no desenvolvimento. Teve-se como objetivo geral identificar habilidades sociais, problemas de comportamento, desempenho acadêmico e recursos familiares de crianças com TDAH e, como específico, comparar alunos quanto a indicadores de TDAH e uso ou não de medicação. Participaram 43 estudantes $(M=9,6$ anos, $D P=1,5)$ do Ensino Fundamental I, 43 responsáveis $(M=39,1$ anos, $D P=7,6)$ e 38 professoras $(M=43,1$ anos, $D P=8,4)$. Os instrumentos utilizados foram Inventário de Habilidades Sociais, Problemas de Comportamento e Competência Acadêmica (SSRS-BR), Escala de Conners e Inventário de Recursos Familiares. A coleta foi realizada em escolas públicas. Os resultados apontaram alunos com escores superiores à amostra de referência em Problemas de Comportamento e Habilidades Sociais, e inferiores em classes de Habilidades Sociais e Competência Acadêmica; recursos familiares presentes e; notas acima de 5,0 como média escolar. Conclui-se a necessidade de intervenções com a população estudada.

Palavras-chave: TDAH, habilidades sociais, problemas de comportamento, desempenho acadêmico e recursos familiares.
\end{abstract}

\section{Estudiantes con TDAH: Habilidades Sociales, Problemas de Comportamiento, Rendimiento Académico y Recursos Familiares}

\begin{abstract}
Resumen
TDAH constituye riesgo de desarrollo. El objetivo general era identificar habilidades sociales, problemas de comportamiento, rendimiento académico y recursos familiares de niños con TDAH; qué tan específico es comparar estudiantes con respecto a los indicadores de TDAH y el uso de medicamentos. Participaron 43 estudiantes $(\mathrm{M}=9.6$ años, $\mathrm{SD}=1.5)$ de la escuela primaria, 43 padres $(M=39.1$ años, $S D=7.6)$ y 38 maestros $(M=43.1$ años, $S D=8.4)$. Los instrumentos utilizados fueron: Inventario de Habilidades Sociales, Problemas de Comportamiento y Competencia Académica (SSRS-BR), Escala de Conners e Inventario de Recursos Familiares. La colección se realizó en escuelas públicas. Los resultados mostraron estudiantes con puntajes más altos que la referencia en Problemas de comportamiento y habilidades sociales y más bajos en clases de habilidades sociales y competencia académica; recursos familiares presentes; calificaciones promedio de la escuela superiores a 5.0. Concluye la necesidad de intervenciones.

Palabras clave: TDAH; habilidades sociales; problemas de comportamiento; desempeño académico y recursos familiares.
\end{abstract}

According to the Diagnostic and Statistical Manual of Mental Disorders - DSM 5, Attention Deficit/ Hyperactivity Disorder (ADHD) is characterized by persistent patterns of inattention, impulsivity and hyperactivity, impairing the individual's social functioning. It does not have a causal biological marker and, although specific genes are related, they are not necessary or sufficient factors for its appearance. It is considered the most common neuropsychiatric condition in children, affecting from 6 to $9 \%$ of the population (APA, 2014; Barkley, 2002).

In view of the global context in which a considerable portion of the population has ADHD, debates arise over conflicts in the diagnosis. The increase in 
diagnosed cases, as well as the increase in medication prescriptions and legal processes that support rights in relation to education and the work environment, the diagnosis of ADHD remains under suspicion (Caliman, 2008), since failures can occur in the identification and performance of treatment (Cruz, Lemos, Piani, \& Brigagão, 2016), leading to false positives for the disorder. In order to avoid these types of errors, authors recommend a multimodal assessment, carried out by a multidisciplinary team, using different techniques and informants (Barkley, 2002; Caliman, 2008; Pelham et al., 2016).

Children with ADHD have different educational needs, due to the presence of behavioral patterns (difficulties in interpersonal relationships with adults and peers) and impaired academic performance (difficulties in completing tasks within the established time, need to move around, among others) that predict risks of school exclusion (Rocha \& Del Prette, 2010). According to the meta-analysis of Gwerman et al. (2016), children with the disorder are at risk of being stigmatized and excluded in the school environment, as they experience frequent situations of violence (verbal and physical aggression) and rejection by their peers. Garcia (2013) discussed the impact of the school context and difficulties experienced by students with ADHD, highlighting the need for expanded teacher training to fulfill the different requirements and assist in the development of the student. They emphasized that in the national panorama the maintenance of hegemonic knowledge is still seen, with a lack of pedagogical debate and discussions that evaluate the performance of the teachers.

In this scenario, the Bioecological Theory of Human Development (BTHD) was adopted as the basis of the present study, as it considers that the relationships established by people in the different systems (microsystem, mesosystem, exosystem and macrosystem) that directly or indirectly participate (Bronfenbrenner, 1996). The author stressed that all developmental results come from the person's characteristics, the contexts and the proximal processes that they establish. Leme, Del Prette, Koller and Del Prette (2016) indicated that according to the BTHD, as well as in the theoretical-practical field of social skills, the socialization process is marked by the interdependence and mutual influence of the developing person with the immediate and remote contexts, as well as the processes that occur in them. They also emphasized that the quality of interpersonal relationships is essential for understanding human development. From this perspective, we aimed to comprehend the presence of behavioral problems, social skills and family resources/ adversities in students with ADHD.

The literature highlights that social skills compete with behavior problems, being important for academic success and relationships with peers and acting as a protective factor in human development (Elias \& Amaral, 2016). Social skills are defined as a repertoire of social behaviors, valued in a given culture, which contribute to the quality of the interaction with peers, as they have a high probability of generating favorable consequences for the individual as well as for their group and wider community (Del Prette \& Del Prette, 2019; Del Prette \& Del Prette, 2017).

The importance of social skills in the life cycle seems evident when considering them in individuals with $\mathrm{ADHD}$, however, there is little national scientific production on the theme (Abrahão, Elias, Zerbini, \& D'Ávila, 2020). Guidolim, Ferreira and Ciasca (2013) found that individuals with ADHD have deficits in social skills such as empathy and civility. The findings of Freitas and Del Prette (2013) indicate that children with ADHD have a greater deficit in the total score and subscales of social skills compared to other types of children with special needs.

Behavior problems are in competition with social skills (Gresham, 2009). In this study we adopted a functional definition that determines behavior problems as behavioral deficits or excesses that impair the child's interaction with the peers and adults they coexist with (Bolsoni-Silva, 2003). These problems can be classified into two major groups, namely, externalizing problems that express themselves in relation to other people and internalizing ones that express themselves in relation to the individual (Achenbach \& Edelbrock, 1979). Both categories of behavioral problems can lead to difficulties in the individual's interaction with the environment since, even if maintained through reinforcements, they are accompanied by negative by-products that damage relationships (Falcão \& Bolsoni-Silva, 2016). Patterson, DeBaryshe and Ramsey (1989), indicate that interpersonal difficulties in a moment of development can influence later moments, accentuating the occurrence of conduct problems, which in turn, can lead to rejection by the peer group and even by parents and teachers, as well as school failure and psychopathologies. Therefore behavior problems are important in the development of the life cycle for individuals with or without ADHD. 
Regarding the behavior problems present in children with ADHD, a higher incidence of the symptoms of hyperactivity and impulsivity are reported, affecting social interactions at school and academic performance (Dias, Rosa, \& Andrade, 2015; Rosello, Berenguer, Baixauli, \& Miranda, 2016). The difficulties in the area of social participation occur mainly due to the difficulty in following rules, low tolerance to frustration and the lack of attention during the execution of tasks (Barkley, 2002; Piscalkiene, 2009). The most frequent functional impairments of ADHD involve reduced schooling, professional achievements and intellectual scores (compared to peers), dimensions that are engendered by the performance of teachers, as they can help these people to access higher quality learning. In the social sphere, children with ADHD are even more likely to develop other disorders such as conduct disorders in adolescence, antisocial personality and substance use, with a greater possibility of being imprisoned in adulthood (APA, 2014; Barkley, 2002). Parents and teachers present similar assessments regarding the identification of externalizing behavior problems in children with ADHD (Bolsoni-Silva, Perallis, \& Nunes, 2018; Rescorla et al., 2014).

Academic difficulties can occur in children with ADHD and are related to the failure to finish tasks, with the presence of disruptive behavior during activities in class and deficient relationships with peers. Deficits in the areas of reading, spelling, mathematics, writing and language, may be present in a minority of children with ADHD, and authors in the area recommend educational support to minimize these difficulties (Barkley, 2002). In general, low academic performance is understood as performance below the level expected for an individual's age, ability and potential (Marturano \& Elias, 2016), while academic competence is an indicator of psychosocial adjustment, correlating positively with social skills and negatively with learning difficulties (Del Prette, Freitas, Bandeira, \& Del Prette, 2016).

The occurrence of skillful and problematic behaviors in children is related to the contexts of interaction (Bolsoni-Silva \& Loureiro, 2019), with the emphasis placed on the family microsystem in the present study. It is evident that among the functions of the family with its children, care, socialization and protection stand out (Marturano \& Elias, 2016). Family resources were considered a protective factor in children with ADHD in the studies by Ray, Evans and Langberg (2017) and Bhide, Sciberras, Anderson, Hazell and Nicholson (2017), which identified the resources provided by families as a healthy potentializer considering the difficulties inherent in the disorder.

Other resources from different microsystems may be present, such as medication and psychological interventions. According to Moysés and Collares (2013), Brazil is the second largest consumer of the psychostimulant Ritalin in the world, behind the USA. The use of medication is shown to be important when applied to diagnoses well-established by multidisciplinary teams, however, this does not always occur and may imply malpractices that do not help in the care of the individual. With regard to psychological interventions, there are different models, aimed at the individuals themselves, the family and the school. Studies indicate that these interventions significantly contribute to the development of people with ADHD (Pelham et al., 2016; Oliveira, \& Dias, 2018) and that pharmacological and psychological treatments are more effective when combined, when compared to individual administration (Barkley, 2002; Fernández-Jaén, 2016; Pelham et al., 2016; Taft, Ayatizadeh, Dehghan, Machado, \& Wegner, 2015).

Considering the aspects addressed, this study aimed to identify the social skills, behavioral problems and academic performance of children with ADHD, and their family resources. As a specific objective, groups were compared regarding ADHD indicators and the use or not of medication.

\section{Method}

\section{Participants}

The sample consisted of 124 participants, these being 43 children (seven girls and 36 boys, mean age 9.6 years, $S D=1.5$ years) regularly enrolled in Elementary Education I, distributed in 19 municipal public schools in a city in the state of São Paulo, 43 parents/legal guardians (38 mothers, two grandmothers, two fathers and one grandfather, mean age 39.1 years, $S D=7.6$ years) and 38 teachers (mean age 43.1 years, $S D=8.4$ years; mean time since graduation of 16.6 years, $S D=1.4$ years). The inclusion criterion was agreeing to participate (all respondents) and for the participating students it was also necessary to have a medical report registered with the Municipal Education Department that confirmed the clinical condition of ADHD. Exclusion criteria were students that had other comorbidities that could influence their social and academic development.

Regarding the socioeconomic level of the families, evaluated through the Criterion Brazil (Brazilian Association of (Market) Research Companies-ABEP, 
2018), 39 families were classified in classes D and E and 4 families in class C. Regarding the characterization of the sample of children, of the 43, 31 used medication for ADHD and 12 did not at the time of data collection.

\section{Instruments}

The instruments used in this study were:

- Social Skills Rating System/Inventory of Social Skills, Behavior Problems and Academic Competence (SSRS$B R)$ : version for teachers, parents and children (Del Prette et al., 2016). This scale was originally developed by Frank M. Greshman and Stephen N. Elliot, in the United States. The SSRS is an instrument that evaluates the repertoire of social skills and indicators of behavior problems and academic competence of children from 6 to 13 years of age (in the $1^{\text {st }}$ to $5^{\text {th }}$ years of elementary education). The three versions were used in this study. In the parents' version, the composite reliability values for the factorial structures of Social Skills (F1 - Responsibility=.69, F2 - Selfcontrol=.73, F3 - Affectivity/Cooperation $=.62$, F4 - Social Resourcefulness $=.65$ and F5 - Civility $=.63)$ and Behavior Problems (F1 - Externalizing problems $=.84$ and F2 - Internalizing problems $=.64)$ were considered reasonable. In the children's version, the composite reliability values were below expectations for the Social Skills Scale (F1 - Empathy / Affectivity=.52, F2 - Responsibility $=.58, \mathrm{~F} 3$ - Self-control / Civility $=.49$ and F4 - Assertiveness=.34). While in the teachers version high values of composite reliability were found for the factorial structures of the Social Skills subscale (F1 - Responsibility=.91, F2 - Self-control=.85, F3 - Assertiveness/Social Resourcefulness $=.80$ and F4 - Cooperation/Affection=.86) and the Behavior Problems subscale ( F1 - Externalizing Problems $=.90$, F2 - Hyperactivity $=.85$, F3 Internalizing Problems $=.77$ and F4 - Academic Competence $=.98$ ).

- Academic performance means: The student's academic performance was verified through the student's report card for the first semester of 2018. The expected mean in the school is 5.0.

- Conners' Scale (CPTRS) - versions for parents and for teachers: Conners' scales are the most used assessment tools in the clinical diagnosis of ADHD, between the ages of 6 and 14 years, covering all teaching cycles. There are two scales, one for parents and one for teachers, and two versions, a full version and a reduced version, which was used in this study. The reduced version of the scales for parents and teachers, consists of 42 and 39 items, respectively, assessing the dimensions: opposition, cognitive problems/ inattention, hyperactivity, antisocial conduct and ADHD index, which considers the core characteristics of ADHD. The percentage of variance of the measured construct was $39.2 \%$, with the cutoff point being 68 for girls and 66 for boys, in the Teachers version, while in the Parents version the internal consistency index was $0.79 \%$ and the cut-off point 57 , for both sexes. The items in the Teachers version are divided into 4 factors: Factor 1 - Hyperactivity $=.91$, Factor 2 - Inattention $=.80$, Factor 3 - Passivity $=.73$ and Factor 4 - Antisocial conduct $=.60$. In the Parents version, the items are also divided into 4 factors: Factor 1 - Hyperactivity $=.83$, Factor $2-$ Fears $/$ Somatization $=.74$, Factor 3 - Perseverance/Perfectionism $=.67$ and Factor 4 - Thefts/Antisocial conduct=.62 (Gaião \& Barbosa, 2008).

- Inventory of Family Environment Resources (Inventário de Recursos do Ambiente Familiar - RAF) (Marturano, 1999). The RAF is composed of ten topics, corresponding to the resource areas presented by the family. The inventory is used to investigate the parental resources in children that present school complaints. In this study, the 10 -question version of the inventory was used, which was validated in the study by Marturano, Ferreira and D'AvilaBacarji (2005), where adequate internal consistency was also identified (Cronbach's alpha >.69).

\section{Procedures}

The study was initiated after approval by the Research Ethics Committee (Information Withheld by the Journal) (Authorization No. 70666017.8.0000.5407). At first, authorization for the study was obtained from the Municipal Education Department. Next, the consent of the parents/guardians and teachers was obtained through signing of the consent form and from the children, with the Terms of Assent applied according to the guidelines. The instruments were applied on dates 
(February to June 2018) and times previously scheduled. Initially the collection was carried out with the parents/guardians, applying Conners' Scale, the RAF, SSRS and Brazil Criteria, with an average duration of 40 minutes per person. The SSRS was applied with the students, lasting an average of 10 minutes per person. The collection with the parents/guardians and students was carried out at the school. After this stage, the teachers were given the SSRS to complete and the date of collection was agreed.

\section{Data analysis procedure}

The data obtained were treated according to the propositions of each technique. The results were transferred to spreadsheets of the SPSS version 20 statistical program. Initially, descriptive statistics were calculated for the total sample including mean, standard deviation, median and frequency, where relevant. Before proceeding to the inferential analyses, the normality of the distribution of the variables was verified, using the Kolgomorv-Smirnov test with Lilliefors correction. When this assumption was fulfilled, comparisons were made between the total group and the reference sample using Student's $t$-test. If parametric statistics were not possible, the non-parametric Man-Whitney and Kruskall-Wallis $U$-test alternatives were used.

\section{Results}

The results are presented considering the social skills and behavior problems variables, obtained through the SSRS (teachers, parents and children); academic performance, verified through the school report card; family environment resources, reported through the RAF; ADHD indicators, assessed by Conners' Scale (teachers and parents) and; the comparison of groups regarding the use or not of medication. Table 1 presents the teachers' assessment of the students' behavioral repertoire obtained through the SSRS.

Table 1.

Comparison between participants and reference sample of the SSRS according to teachers - Student's t-test

\begin{tabular}{|c|c|c|c|c|c|c|}
\hline Variables & Group & $n$ & Mean & $S D$ & $t$ & $d$ \\
\hline Social Skills & $\begin{array}{c}\text { Teachers } \\
\text { Reference sample }\end{array}$ & $\begin{array}{c}38 \\
416\end{array}$ & $\begin{array}{l}51.3 \\
47.7\end{array}$ & $\begin{array}{l}10.3 \\
7.0\end{array}$ & $2.13^{*}$ & 0.40 \\
\hline Responsibility & $\begin{array}{c}\text { Teachers } \\
\text { Reference sample }\end{array}$ & $\begin{array}{c}38 \\
416\end{array}$ & $\begin{array}{l}15.7 \\
23.6\end{array}$ & $\begin{array}{l}3.8 \\
4.1\end{array}$ & $-12.84 * * *$ & -1.99 \\
\hline Self-control & $\begin{array}{c}\text { Teachers } \\
\text { Reference sample }\end{array}$ & $\begin{array}{c}38 \\
416\end{array}$ & $\begin{array}{l}17.7 \\
13.4\end{array}$ & $\begin{array}{l}5.0 \\
3.2\end{array}$ & $5.244 * * *$ & 1.02 \\
\hline $\begin{array}{l}\text { Assertiveness and Social } \\
\text { Resourcefulness }\end{array}$ & $\begin{array}{c}\text { Teachers } \\
\text { Reference sample }\end{array}$ & $\begin{array}{c}38 \\
416\end{array}$ & $\begin{array}{l}10.9 \\
15.2\end{array}$ & $\begin{array}{l}2.8 \\
2.6\end{array}$ & $-9.53 * * *$ & -1.59 \\
\hline Cooperation and Affection & $\begin{array}{c}\text { Teachers } \\
\text { Reference sample }\end{array}$ & $\begin{array}{c}38 \\
416\end{array}$ & $\begin{array}{l}6.1 \\
4.1\end{array}$ & $\begin{array}{l}2.6 \\
1.6\end{array}$ & $4.62^{* * *}$ & 0.88 \\
\hline Academic Competence & $\begin{array}{c}\text { Teachers } \\
\text { Reference sample }\end{array}$ & $\begin{array}{c}38 \\
416\end{array}$ & $\begin{array}{l}22.6 \\
36.7\end{array}$ & $\begin{array}{l}9.8 \\
7.2\end{array}$ & $-8.74 * * *$ & -1.63 \\
\hline Behavior Problems & $\begin{array}{c}\text { Teachers } \\
\text { Reference sample }\end{array}$ & $\begin{array}{c}38 \\
416\end{array}$ & $\begin{array}{l}13.0 \\
4.92\end{array}$ & $\begin{array}{l}7.2 \\
4.1\end{array}$ & $2.43^{* *}$ & 1.37 \\
\hline Externalization & $\begin{array}{c}\text { Teachers } \\
\text { Reference sample }\end{array}$ & $\begin{array}{c}38 \\
416\end{array}$ & $\begin{array}{l}5.0 \\
4.1\end{array}$ & $\begin{array}{c}4.2 \\
-\end{array}$ & 1.43 & 0.30 \\
\hline Hyperactivity & $\begin{array}{c}\text { Teachers } \\
\text { Reference sample }\end{array}$ & $\begin{array}{c}38 \\
416\end{array}$ & $\begin{array}{l}4.3 \\
1.4\end{array}$ & $\begin{array}{c}2.7 \\
-\end{array}$ & $6.68^{* * *}$ & 1.51 \\
\hline Internalization & $\begin{array}{c}\text { Teachers } \\
\text { Reference sample }\end{array}$ & $\begin{array}{c}38 \\
416\end{array}$ & $\begin{array}{l}3.6 \\
-\end{array}$ & $\begin{array}{l}2.0 \\
-\end{array}$ & - & - \\
\hline
\end{tabular}

Note: $S D=$ Standard Deviation, $t=$ test for a sample; $* \leq .05 ; * * p \leq .01 ; * * * p<.001 ; d=$ Cohen's $d$ effect size. 
Table 1 demonstrates that, in the teachers' evaluation, the study participants showed significant differences compared to the reference sample in the majority of the variables. The participants' performance was superior in the total of Social Skills, Self-Control, Cooperation and Affectivity, Behavior Problems and Hyperactivity. However, the participants presented significantly lower results in Responsibility, Assertiveness and Social Resourcefulness and Academic Competence. The effect size varied from small to very large. Table 2 presents the parents/guardians assessment of the students' behavioral repertoire obtained through the SSRS.

Table 2 presents the SSRS results according to the parents, demonstrating significant differences in the means of 8 of the 9 variables evaluated, with only the Affectivity and Cooperation variable presenting no significant difference. According to the parents, the participants achieved superior results in Social Skills, Civility, Behavior Problems, Externalization and Internalization, and inferior results in Responsibility, Self-Control and Assertiveness and Social
Resourcefulness. The effect size varied from small to very high. Table 3 presents the children's self-assessment regarding their behavioral repertoire, through the SSRS.

Table 3 presents the results, according to the students themselves (self-report), showing that the sample of participants presented lower means with significant differences in the variables: Social Skills, Empathy and Affection, Self-Control and Civility and Assertiveness, and higher means in Responsibility. The effect size varied from small to very high.

Academic performance was assessed through the grades recorded on the student's report card. It should be noted that, in the population of the present study, 5.0 was the mean for approval in the disciplines. The results showed that in Portuguese, the students were average $(M=5.0 ; S D=1.8)$ and above average in History $(M=5.2 ; S D=1.9)$, Geography $(M=5.4 ; S D=1.9)$, Mathematics $(M=5.4 ; \quad S D=2.1)$, Science $(M=5.4$; $S D=1.9)$, Arts $(M=6.5 ; S D=1.5)$, Physical Education $(M=6.7 ; S D=1.4)$ and Total Mean $(M=5.4 ; S D=2.1)$.

Table 2.

Comparison between participants and reference sample of the SSRS according to parents - Student's t-test

\begin{tabular}{|c|c|c|c|c|c|c|}
\hline Variables & Group & $n$ & Mean & $S D$ & $t$ & $d$ \\
\hline Social Skills & $\begin{array}{c}\text { Parents } \\
\text { Reference sample }\end{array}$ & $\begin{array}{c}43 \\
416\end{array}$ & $\begin{array}{l}53.8 \\
50.3\end{array}$ & $\begin{array}{l}9.0 \\
8.0\end{array}$ & $2.55^{* *}$ & 0.41 \\
\hline Responsibility & $\begin{array}{c}\text { Parents } \\
\text { Reference sample }\end{array}$ & $\begin{array}{c}43 \\
416\end{array}$ & $\begin{array}{c}8.5 \\
12.2\end{array}$ & $\begin{array}{l}2.8 \\
3.3\end{array}$ & $-8.54 * * *$ & -1.20 \\
\hline Self-control & $\begin{array}{c}\text { Parents } \\
\text { Reference sample }\end{array}$ & $\begin{array}{c}43 \\
416\end{array}$ & $\begin{array}{l}10.3 \\
12.7\end{array}$ & $\begin{array}{l}2.0 \\
2.2\end{array}$ & $-7.74 * * *$ & -1.14 \\
\hline Affection and Cooperation & $\begin{array}{c}\text { Parents } \\
\text { Reference sample }\end{array}$ & $\begin{array}{c}43 \\
416\end{array}$ & $\begin{array}{l}12.3 \\
12.4\end{array}$ & $\begin{array}{l}2.6 \\
2.7\end{array}$ & -0.19 & -0.37 \\
\hline $\begin{array}{l}\text { Assertiveness and Social } \\
\text { Resourcefulness }\end{array}$ & $\begin{array}{c}\text { Parents } \\
\text { Reference sample }\end{array}$ & $\begin{array}{c}43 \\
416\end{array}$ & $\begin{array}{c}8.6 \\
12.9\end{array}$ & $\begin{array}{l}2.4 \\
2.5\end{array}$ & $-11.54 * * *$ & -1.75 \\
\hline Civility & $\begin{array}{c}\text { Parents } \\
\text { Reference sample }\end{array}$ & $\begin{array}{c}43 \\
416\end{array}$ & $\begin{array}{c}11.0 \\
7.9\end{array}$ & $\begin{array}{l}2.4 \\
2.0\end{array}$ & $8.61 * * *$ & 1.40 \\
\hline Behavior Problems & $\begin{array}{c}\text { Parents } \\
\text { Reference sample }\end{array}$ & $\begin{array}{c}43 \\
416\end{array}$ & $\begin{array}{l}19.4 \\
10.2\end{array}$ & $\begin{array}{l}4.9 \\
4.1\end{array}$ & $12.44^{* * *}$ & 2.03 \\
\hline Externalization & $\begin{array}{c}\text { Parents } \\
\text { Reference sample }\end{array}$ & $\begin{array}{c}43 \\
416\end{array}$ & $\begin{array}{c}13.0 \\
4.4\end{array}$ & $\begin{array}{l}3.7 \\
2.3\end{array}$ & $15.33^{* * *}$ & 2.79 \\
\hline Internalization & $\begin{array}{c}\text { Parents } \\
\text { Reference sample }\end{array}$ & $\begin{array}{c}43 \\
416\end{array}$ & $\begin{array}{l}6.5 \\
4.4\end{array}$ & $\begin{array}{l}2.0 \\
1.9\end{array}$ & $6.76^{* * *}$ & 1.07 \\
\hline
\end{tabular}

Note: $\mathrm{SD}=$ Standard Deviation, $t=$ test for a sample; $* x \leq .05 ; * * p \leq .01 ; * * * p<.001 ; d=$ Cohen's $d$ effect size. 
Table 3.

Comparison between participants and reference sample in the SSRS according to children - Student's t-test

\begin{tabular}{lcccccc}
\hline Variables & Group & $n$ & Mean & $S D$ & $t$ & $d$ \\
\hline Social Skills & Children & 43 & 25.6 & 5.30 & & -3.04 \\
& Reference sample & 416 & 41.5 & 5.14 & $-19.92^{* * *}$ & \\
Empathy and Affection & Children & 43 & 7.0 & 2.40 & & -3.07 \\
& Reference sample & 416 & 13.8 & 2.00 & $-18.35^{* * *}$ & \\
Responsibility & Children & 43 & 7.2 & 1.60 & & 0.73 \\
& Reference sample & 416 & 6.1 & 1.38 & $4.43^{* * *}$ & \\
Self-Control and Civility & Children & 43 & 8.1 & 1.80 & & -1.35 \\
& Reference sample & 416 & 10.9 & 2.30 & $-10.17^{* * *}$ & \\
Assertiveness & Children & 43 & 3.4 & 1.90 & & -2.89 \\
& Reference sample & 416 & 8.1 & 1.29 & $-16.39 * * *$ & \\
\hline
\end{tabular}

Note: $\mathrm{SD}=$ Standard Deviation, $t=$ test for a sample; $* x \leq .05 ; * * p \leq .01 ; * * * p<.001 ; d=$ Cohen's $d$ effect size.

The family resources present in the family microsystem were verified through the Family Resources Inventory $(\mathrm{R} A F)$. The results showed that the families presented scores $(M=67.6 ; S D=13.6)$ higher than the mean of the instrument $(M=59.5)$.

Even though all the students had a report of ADHD, a screening for the presence of ADHD was carried out using Conners' Scale for parents and teachers. Values indicative of ADHD were observed according to the evaluation of parents for 16 children (10 boys and 6 girls) and; for 4 children (boys), according to the teachers' assessment. There was agreement between the evaluators (parents and teachers) regarding the presence of ADHD for only three children; evidenced by manually crossing the data.

In all the subscales of Conners' Scale, according to the teachers' evaluation, the participants presented lower means compared to the instrument's means in: Hyperactivity $(M=18.6, S D=13.1)$, Antisocial Conduct $(M=1.9, S D=2.3)$, Inattention $(M=13.2, S D=5.6)$ and Passivity $(M=6.7, S D=4.0)$. Regarding the values obtained in the parents' evaluation for the subscales of Conners' Scale, the participants presented higher values in Hyperactivity $(M=20.0, S D=7.0)$ and Perseveration/Perfectionism $(M=12.9, S D=3.4)$, however, these values were only slightly higher than the mean of the instrument. In the variables Fears/Somatization $(M=9.8, S D=4.5)$ and Theft/Antisocial Conduct $(M=0.3, S D=0.7)$, the values were below the mean indicated by the instrument.
In the comparative analysis between the Clinical and Non-Clinical groups, constituted according to the cut-off score resulting from Conners' Scale, the scores obtained through the SSRS, according to the teachers' assessment, for the Clinical group showed higher means, with significant differences in Assertiveness and Social Resourcefulness ( $W=82.0, p<.05$ ), Behavior Problems $(W=103.0, p<.05)$ and Hyperactivity $(W=88.0, p<.05)$ compared to the Non-Clinical group. In the evaluation carried out by the parents, the Clinical group presented higher scores with significant differences in Behavior Problems ( $W=61.5, p<.05)$, Externalization $(W=58.0$, $p<.05)$ and Internalization ( $W=128.0, p<.05)$.

Analyses were performed comparing the groups formed by children who used or did not use medication for ADHD, regarding the SSRS results, according to the teachers, parents and children. A significant result was found only according to the children's self-assessment in the total social skills variable ( $W=266.5, p<.05)$, in which the non-medication user group presented a higher score.

\section{Discussion}

This study aimed to identify the social skills, behavioral problems and academic performance of children with ADHD, and their family resources. As a specific objective, groups were compared regarding ADHD indicators (according to a specific instrument) and the use or not of medication. 
Regarding social skills and behavioral problems, it was observed that the parents and teachers evaluated the children in a similar way, reporting good performance in total social skills and in specific classes. They also indicated their perception of difficulties in some classes of skills such as assertiveness/social resourcefulness and responsibility. These results are partially contrary to those observed by Freitas and Del Prette (2013), who found greater deficits in total social skills and in specific subscales in children with ADHD, according to the evaluation of teachers. The results of the present study also disagree with those found by Guidolim, Ferreira and Ciasca (2013), which showed deficits in civility in individuals with ADHD, with our participants presenting better results than the reference sample, according to the parents.

Concerning behavior problems, again, parents and teachers were in agreement in their assessments, recognizing the children as having greater total behavioral difficulties. The teachers reported greater behavior problems related to hyperactivity, while the parents/ guardians related these to externalization and internalization. These findings are consistent with the literature, which indicates that children with ADHD have greater behavior problems, highlighting hyperactivity and impulsivity (Bolsoni-Silva et al., 2018; Dias et al., 2015; Rescorla et al., 2014; Rosello, et al., 2016).

Parents and teachers not only observed behavioral difficulties in the children, but also resources (social skills). However, the children referred only to the lack of resources, self-rated more negatively (performance below the reference sample), both in terms of total social skills and in the majority of subclasses. These findings corroborate the study by Piscalkiene (2009) that identified that the self-evaluations of children with ADHD were more critical in relation to their characteristics and behaviors, when compared with the teachers' evaluations. These results show that, on the one hand, the parents and teachers seemed to be able to separate the difficulties and resources presented by the children (which is positive), while on the other hand, the children demonstrated feelings of worthlessness (a worrying factor), which may be associated with the difficulties they experience in the school relationships. These data are in line with studies that indicated that the presence of social difficulties compromises and impairs interactions, as well as the academic performance of people with ADHD (Dias et al., 2015; Rosello et al., 2016).

Regarding the identification of ADHD via Conners' Scale, there was a difference between evaluators, given the higher incidence of the disorder for the parents $(n=16)$ than for the teachers $(n=4)$. As a complement to this analysis, crossing of the data was performed, which verified the convergence of ADHD indication for only 3 children in the sample. These results are in line with the literature, which highlights the consistently greater presence of the disorder according to the parents' assessment (Soma, Nakamura, Oyama, Tsuchiya, \& Yamamoto, 2009). It can be inferred that parents are more severe evaluators because their possibility of comparison with other children is limited when compared to that of teachers and also due to their expectations as a parent, among other possibilities.

This divergence among evaluators regarding the perception of behaviors related to the diagnosis of ADHD brings to light, once again, relevant issues emphasized in the literature. Among these, the importance of the ADHD diagnosis being carried out by a multidisciplinary team and reflections on the use of medication stand out (Barkley, 2002; Caliman, 2008; Pelham et al., 2016; Haack, Villodas, McBurnett, Hinshaw, \& Pfiffner, 2016).

Refining the analyses by dividing the children between the clinical group (ADHD indicator) and the non-clinical group (without indicator) using the Conners' Scale cut-off score, different results were observed. According to the teachers, the clinical group revealed greater resources in Assertiveness and Social Resourcefulness, and higher rates in Behavior Problems and Hyperactivity. A possible explanation for the presence of greater resources in assertiveness may be associated with the benefit of aggressiveness, when used by children as a means to achieve their social goals, which can even guarantee them a significant and popular social role, as discussed by Farmer and Xie (2007).

According to the parents, the clinical group presented greater behavioral difficulties, without observing resources. These results are in line with the literature, which indicates parents as the most severe evaluators (Soma, Nakamura, Oyama, Tsuchiya, \& Yamamoto, 2009).

In the analysis carried out comparing groups regarding the use or not of medication, with regard to performance in the SSRS according to the different informants, there was only a significant difference in the self-assessment of the children, which occurred in the total social skills variable, in which the group that did not use medication presented a higher mean. Batistela, Bueno, Vaz and Galduróz, (2016) evaluated the effect of administering different doses of methylphenidate in 
young people with ADHD, focusing on cognitive functions and found no differences.

Regarding academic performance, obtained through the grades from the school report, the participants presented average and above average values considering the reference values of the schools in different subjects, indicating that, despite their behavioral difficulties, they could achieve satisfactory performance when evaluated objectively. Barkley (2002) pointed out that learning difficulties occur in a minority of children with ADHD and their difficulties are due to their behaviors, indicating the need for specific pedagogical support so that their behavioral difficulties do not affect their performance.

When verifying the results of academic competence (subjective evaluation carried out by the teachers), obtained via the SSRS, the participants were evaluated as having skills that put them below the best $50 \%$ of their class. What at first may seem like an incongruity between objective and subjective assessments is not, when considering that these children are part of the educational system of continuous progression and that having average or above grades (the school mean) does not signify being among the best in the class. According to Bolsoni-Silva et al. (2018) children that showed behavior problems at home and school showed less social and academic competence. Gwerman et al. (2016), in a meta-analysis, identified that children with ADHD are at risk of being stigmatized and excluded in the school environment, due to factors other than academic performance. Sherman, Rasmussen and Baydala (2008), emphasized how much teachers can be an integral component to maximize the potential of students with ADHD.

Finally, the family resources present in the lives of these children with ADHD were verified. The results showed that despite the economic difficulties presented by most of the families (belonging to the socioeconomic classes $\mathrm{D}$ and $\mathrm{E}$ according to the Brazil Criterion), they obtained scores above average with regard to family resources (verified by the RAF), which indicated good values regarding Supervision/Routine, Parent Interaction and Physical Resources. These results highlight the importance and the role of family resources as a protective factor for development. The findings corroborate the literature in the area, which demonstrates that greater family resources seem to be associated with better scores in the social skills and academic performance of children (Marturano, 1999). In addition, parental involvement tends to be an enhancer of healthy social functioning in children with ADHD (Ray et al., 2017) and the resource provided by parents is positively related to children's prosocial behavior and responsibility (Bhide et al., 2017).

The data discussed highlight the importance of considering and understanding the different systems (microsystem, mesosystem, exosystem and macrosystem) that the individual directly or indirectly participates in when their development is considered (Bronfenbrenner, 1996; Leme et al., 2016). Within this perspective, we can better understand the real difficulties, needs and resources of the population studied and then develop more effective and efficient interventions

\section{Final considerations}

In general, this study aimed to identify the social skills, behavioral problems and academic performance of children with ADHD, and their family resources. As a specific aim, groups were compared regarding ADHD indicators (according to a specific instrument) and the use or not of medication. In summary, the results showed that the children presented scores above the reference mean in total social skills and in specific subclasses, according to parents and teachers; behavior problems marked by hyperactivity, externalization and internalization; average or above average academic performance in the different disciplines investigated; and the presence of family resources, despite financial difficulties. When considering the clinical and non-clinical groups, according to Conners' Scale, differences in subclasses of social skills and behavioral problems were noted. When comparing groups according to the use or not of medication, a significant difference was only found in the total social skills variable, in the selfreports of the children.

This study provides data from multi-informants (which is rare in the national context) corroborating the literature on some points and highlighting others to be considered and investigated further. It should be emphasized that in this work there was no direct manipulation of variables, however, the nature of the study identified a larger set of these that can be tested in the future. Further studies should involve contingency analysis that maintains the behavior problems presented by the participants; evaluation of educational practices used by parents and teachers and; the use of direct observation in the microsystems. These considerations could contribute to a greater and better comprehension of 
aspects that could support interventions for individuals with ADHD and for their educators.

\section{References}

Abrahão, A. L. B., Elias, L. C. S., Zerbini, T., \& D’Avila, K. M. G. (2020). Transtorno de déficit de atenção e hiperatividade, inclusão educacional e treinamento, desenvolvimento e educação de pessoas: uma revisão integrativa. Revista Psicologia: organizações e trabalho, 20(2), 1025-1032. doi: 10.17652/ rpot/2020.2.18885

Achenbach, T. M., \& Edelbrock, C. S. (1979). The Child Behavior Profile: II. Boys aged 12-16 and girls aged 6-11 and 12-16. Journal of consulting and clinicalpsychology, 47(2), 223. doi: 10.1037//0022-006x.47.2.223

American Psychiatric Association. (2014). Diagnostic and Statistical Manual of Mental Disorders ( $5^{\mathrm{a}} \mathrm{ed}$.). Arlington, VA: American Psychiatric Association.

Associação Brasileira de Empresas de Pesquisa. (2018). Critério de classificação econômica Brasil. Available at http://www.abep.org.br

Barkley, R. A. (2002). Transtorno de déficit de atenção/ hiperatividade (TDAH): guia completo e autorizado para os pais, professores e profissionais da saúde. Tradução de Luís Sérgio Roizman. Porto Alegre: Artmed.

Batistela, S., Bueno, O. F. A., Vaz, L. J., \& Galduróz, J. C. F. (2016). Methylphenidate as a cognitive enhancer in healthy young people. Dementia \& Neuropsychologia, 10(2), 134-142. doi: 10.1590/S1980-5764-2016DN1002009

Bhide, S., Sciberras, E., Anderson, V., Hazell, P., \& Nicholson, J. M. (2017). Association between parenting style and social outcomes in children with and without attention-deficit/hyperactivity disorder: An 18-month longitudinal study. Journal of Developmental and Behavioral Pediatrics, 38(6), 369377. doi: 10.1177/1087054716661420

Bolsoni-Silva, A. T. (2003). Habilidades sociais educativas, variáveis contextuais e problemas de comportamento: Comparando pais e mães de pré-escolares (Tese de Doutorado não publicada), Universidade de São Paulo, Ribeirão Preto, SP.

Bolsoni-Silva, A. T., Perallis, C., \& Nunes, P. (2018). Behavior problems, social competence and academic performance: A comparative study of children in the school and family environments. Trends in Psychology, 26(3), 1189-1204. doi: 10.9788/ TP2018.3-03Pt

Bolsoni-Silva, A. T., \& Loureiro, S. R. (2019). Práticas parentais: Conjugalidade, depressão materna, comportamento das crianças e variáveis demográficas. Psico-USF, 24(1), 69-83. doi: 10.1590/1413-82712019240106

Bronfenbrenner, U. (1996). A ecologia do desenvolvimento humano: Experimentos naturais e planejados. (M.A.V. Veronese, Trad.) Porto Alegre: Artes Médicas.

Caliman, L. V. (2008). O TDAH: Entre as funções, disfunções e otimização da atenção. Psicologia em Estudo, 13(3), 559-566. doi: 10.1590/ S1413-73722008000300017

Cruz, B. de A., Lemos, F. C. S., Piani, P. P. F., \& Brigagão, J. I. M. (2016). Uma crítica à produção do TDAH e a administração de drogas para crianças. Estudos de Psicologia (Natal), 21(3), 282-292. doi: 10.5935/1678-4669.20160027

Del Prette, P. A. Z., Freitas, C. L., Bandeira, M., \& Del Prette, A. (2016). SSRS: Manual Técnico-Inventário de Habilidades Sociais, Problemas de Comportamento e Competência Acadêmica para Crianças (1 ed.). São Paulo: Casa do Psicólogo.

Del Prette, P. A. Z., \& Del Prette, A. (2017). Habilidades sociais e competência social: para uma vida melhor. São Carlos: EdUFSCAR.

Del Prette, Z. A. P., \& Del Prette, A. (2019). Studies on social skills and social competence in Brazil: A history in construction. In: Koller S. (eds) Psychology in Brazil. Springer. doi: 10.1007/978-3-030-11336-0_4

Dias, M. Á. de L., Rosa, S. C., \& Andrade, P. F. (2015). Os professores e a educação inclusiva: identificação dos fatores necessários à sua implementação. Psicologia USP, 26(3), 453-463. doi:10.1590/0103-656420140017

Elias, L. C. S., \& Amaral, M. V. (2016). Habilidades sociais, comportamentos e desempenho acadêmico em escolares antes e após intervenção. Psico-USF, 21(1), 49-61. doi: 10.1590/1413-82712016210105

Falcão, A. P., \& Bolsoni-Silva, A. T. (2016). Promove-Crianças: Treinamento de habilidades sociais. São Paulo, CETEPP. 
Farmer, T. W., \& Xie, H. (2007). Aggression and school social dynamics: The good, the bad, and the ordinary. Journal of School Psychology, 45(5), 461-478. doi: org/10.1016/j.jsp.2007.06.008

Fernández-Jaén, A., Martín, F. M. M. D., Fernández-Perrone A. L., Calleja-Pérez, B., Albert, J., López-Martín, S., \& López-Arribas, S. (2016). Dysfunction in attention deficit hyperactivity disorder: assessment and response to treatment. Revista de Neurologia, 62, 79-84. doi: 10.33588/ rn.62S01.2015527

Freitas, L. C., \& Del Prette, Z. A. P. (2013). Habilidades sociais de crianças com diferentes necessidades educacionais especiais: Avaliação e implicações para intervenção. Avances en psicología latinoamericana, 31(2), 344-362. Available at http://www. scielo.org.co/scielo.php?script=sci_abstract\&pid =S1794-47242013000200004

Gaião, A. de A., \& Barbosa, G. A. (1998). Estudo epidemiológico dos transtornos hipercinéticos-Normas diagnósticas e validação do Questionário de Conners para Pais e Professores. Infanto-Revista Neuropsiquiátrica da infância e adolescência, 6(1), 21-31. Available at http://www.psiquiatriainfantil.com. br/revista/edicoes/Ed_06_1/in_15_07.pdf

Garcia, R. M. C. (2013). Política de educação especial na perspectiva inclusiva e a formação docente no Brasil. Revista Brasileira de Educação, 18(52), 101-119. Available at https:// www.scielo.br/scielo.php?script $=$ sci_arttext\&pid $=$ S1413-24782013000100007

Guidolim, K., Ferreira, T. de L., \& Ciasca, S. M. (2013). Habilidades sociais em crianças com queixas de hiperatividade e desatenção. Psicopedagogia, 30(93), 159-168. Available at http://www. revistapsicopedagogia.com.br/detalhes/92/ habilidades-sociais-em-criancas-com-queixas-dehiperatividade-e-desatencao

Gresham, F. M. (2009). Análise do comportamento aplicada às habilidades sociais. Em Z. A. P. del Prette \& A. del Prette, A. (Orgs.). Psicologia das habilidades sociais: Diversidade teórica e suas implicacoões (pp. 17-66). Petrópolis: Vozes.

Gwerman, J. R., Moore, D. A., Cooper, P., Russell, A. R., Richardson M., Morwenna R. ... Garside, R. (2016). A systematic review and synthesis of qualitative research: The influence of school context on symptoms of attention deficit hyperactivity disorder. Emotional \& Behavioural Difficulties, 21, 83-100. doi:10.1080/13632752.2015.1120055

Haack, L. M., Villodas, M. T., McBurnett, K., Hinshaw, S., \& Pfiffner, L. J. (2016). Parenting mediates symptoms and impairment in children with ADHDinattentive type. Journal of Clinical Child and Adolescent Psychology, 45(2), 155-166. doi: 10.1080/15374416.2014.958840

Leme, V. B. R., Del Prette, Z. A. P., Koller, S. H., \& Del Prette, A. (2016). Habilidades sociais e o modelo bioecológico do desenvolvimento humano: análise e perspectiva. Psicologia \& Sociedade, 28(1), 181-193. doi: 10.1590/1807-03102015aop001

Marturano, E. M. (1999). Recursos no ambiente familiar e dificuldades de aprendizagem na escola. Psicologia: Teoria e Pesquisa, 15, 135-142. doi: 10.1590/ S0102-37721999000200006

Marturano, E. M., Ferreira, M. C. T., \& D'Avila Bacarji, K. M. (2005). An evaluation scale of family environment for identification of children at risk of school failure. Psychological Reports, 96, 307-321. doi: 10.2466/pr0.96.2.307-321

Marturano, E. M., \& Elias, L. C. S. (2016). Família, dificuldades no aprendizado e problemas de comportamento em escolares. Educar em Revista, (59), 123-139. doi: 10.1590/0104-4060.44617

Moysés, M. A., \& Collares, C. A. L. (2013). Controle e medicalização da infância. Desidades, 1(1), 11-21. Available at https://revistas.ufrj.br/index.php/ desidades/article/view/2456

Oliveira, C. T. de., \& Dias, A. C. G. (2018). Psicoeducação do transtorno do déficit de atenção/ hiperatividade: $\mathrm{O}$ que, como e para quem informar? Temas em Psicologia, 26(1), 243-261. doi: org/10.9788/TP2018.1-10Pt

Patterson, G., Reid, J., \& Dishion, T. (2002). Antisocial boys: Comportamento anti-social. 1 ed. Santo André, SP: Esetec.

Patterson, G. R., DeBaryshe, B. D., \& Ransey, E. (1989). A developmental perspective on antisocial behavior. American Psychologist, 44(2), 329-335. doi: 10.1037//0003-066x.44.2.329

Pelham, W. E., Fabiano, G. A., Waxmonsky, J. G., Greiner, A. R., Gnagy, E. M., Coxe, S. ... Murphy, S. A. (2016). Treatment sequencing for childhood 
ADHD: A multiple-randomization study of adaptive medication and behavioral interventions. Journal of Clinical Child and Adolescent Psychology, 45(4), 396415. doi: 10.1080/15374416.2015.1105138.

Piscalkiene, V. (2009). Experimental Training of Children with Attention Deficit/Hyperactivity Disorder. US-Cbina Education Review, 6(8), 17-30. Available at https://eric.ed.gov/?id=ED506323

Ray, A. R., Evans, S. W., \& Langberg, J. M. (2017). Factors associated with healthy and impaired social functioning in young adolescents with ADHD. Journal of Abnormal Child Psychology, 45(5), 883-897. doi: 10.1007/s10802-016-0217-x

Rescorla, L. A., Bochicchio, L., Achenbach, T.M., Ivanova, M. Y., Almqvist, F., Begovac, I. ... Verhulst, F. C. (2014). Parent-teacher agreement on children's problems in 21 societies. Journal of Clinical Child \& Adolescent Psychology, 43(4), 627-42. doi: 10.1080/15374416.2014.900719

Rocha, M. M., \& Del Prette, Z. A. P. (2010). Habilidades sociais educativas para mães de crianças com TDAH e a inclusão escolar. Psicologia e Argumento, 28(60), 31-41. Available at https://periodicos.pucpr.br/index.php/psicologiaargumento/article/ view/19723/19047

Rosello, M. B., Berenguer, F. C., Baixauli, F. I., \& Miranda, C. A. (2016). Integrating model of the social adaptation of children with attention deficit hyperactivity disorder. Revista Neurologial, 62(1), 85-91. doi: 10.33588/rn.62S01.2015535

Sherman, J., Rasmussen, C., \& Baydala, L. (2008). The impact of teacher factors on achievement and behavioural outcomes of children with attention deficit/hyperactivity disorder (ADHD): A review of the literature. Educational Research, 50(4), 347360. doi: 10.1080/00131880802499803

Soma, Y., Nakamura, K., Oyama, M., Tsuchiya, Y., \& Yamamoto, M. (2009). Prevalence of attentiondeficit/hyperactivity disorder (ADHD) symptoms in preschool children: discrepancy between parent and teacher evaluations. Environmental Health and Preventive Medicine, 14(2), 150-154. doi: 10.1007/ s12199-008-0075-4

Taft, Y. S. N., Ayatizadeh, F., Dehghan, F., Machado, S., \& Wegner, M. (2015). Comparing the effects of drug therapy, perceptual motor training, and both combined on the motor skills of schoolaged attention deficit hyperactivity disorder children. CNS and Neurological Disorders-Drug Targets, 14(10), 1283-91. doi: 10.2174/187152731566 6151111123501

Recebido em: 30/07/2019

Reformulado em: 07/05/2020 Aprovado em: 07/09/2020 
About the authors:

Anaísa Leal Barbosa Abrahão - PhD student in Psychology at the Faculty of Philosophy, Sciences and Letters, Ribeirão Preto - FFCLRP, University of São Paulo and Clinical Psychologist.

ORCID: https://orcid.org/0000-0002-2548-1846.

E-mail: anaisaleal@hotmail.com / anaisaleal@usp.br

Luciana Carla dos Santos Elias - Professor of Undergraduate and Graduate Studies of the Department of Psychology at the Faculty of Philosophy, Sciences and Letters, Ribeirão Preto - FFCLRP, University of São Paulo.

ORCID: https://orcid.org/0000-0002-1623-0674

E-mail:lucaelias@ffclrp.usp.br

\section{Contact:}

Av. Doutor Ismael Alonso y Alonso, 2736

Franca-SP, Brasil

CEP: 14403-000

Telefone: + 55 (16) 99245-4805 
